\title{
THE RISK OF MULTIPLE SCLEROSIS DEVELOPING IN PATIENTS WITH ISOLATED IDIOPATHIC OPTIC NEURITIS IN BRAZIL
}

\author{
MARCO AURÉLIO LANA-PEIXOTO * - MARIA INÊS VILHENA LANA-PEIXOTO *
}

SUMMARY - We studied 88 patients with isolated idiopathic optic neuritis (IION) in order to evaluate the rate of progression to multiple sclerosis (MS) in Brazil. The patients were reassessed from one month to nine years after the development of the HON (mean follow-up was 4.6 years). There were 52 men and 36 women with ages ranging from three to 59 years (mean 24.3 years). Bilateral optic neuritis occurred in 19 patients whereas sequential involvement of the fellow eye after an interval longer than four weeks occurred in other 19 patients. Recurrences in the same eye occurred in seven cases. Nine patients (10.8\%) developed clinically definitive MS - 13.9\% of the women and $7.7 \%$ of the men with IION. The median age at the time of diagnosis of MS was 25 years. The mean interval between HON and the emergence of other MS signs varied from one month to five years - median one year. Sixty-seven percent of these, patients developed signs of spinal cord involvement. Our findings when compared to published series in different countries are closer to figures reported in Japan than those in the West.

Risco de desenvolvimento de esclerose múltipla em pacientes com neurite óptica idiopática isolada no Brasil.

RESUMO - O risco de progressão da neurite óptica idiopática isolada (NOH) para esclerose múltipla (EM) ainda não está bem definido, com taxas variáveis dependendo de critérios de diagnóstico, tempo de follow-up, fatores genéticos, raciais e, possivelmente geográficos. Com o propósito de estudar a taxa de desenvolvimento de EM em pacientes com NOIÍ, um grupo de 88 pacientes (52 homens e 36 mulheres) com NOII foi seguido por período de 1 mês a 9 anos (média 4,6 anos). Em 19 pacientes a neurite óptica foi bilateral, ou seja, ocorreu simultaneamente ou em intervalo até 4 semanas nos dois olhos; enquanto em outros 19 pacientes ela foi seqüencial, afetando o olho contralateral após intervalo maior que um mês. Recorrências afetando o mesmo olho foram observadas em 7 pacientes. Nove pacientes $(10,8 \%)$ com NOII desenvolveram sinais de EM entre 1 mês e 5 anos após o primeiro episódio de neurite óptica, o intervalo mediano sendo 1 ano. Estes pacientes representavam $13,9 \%$ das mulheres e $7,7 \%$ dos homens com NOII e a mediana das idades foi 25 anos. Dois terços dos pacientes que desenvolveram EM apresentaram envolvimento predominantemente medular. Nossos achados, em relação à taxa de progressão da NOII para EM assim como à predileção por envolvimento espinal, se assemelham mais aos dados publicados no Japão que em países ocidentais.

It has been well established that optic nerve involvement almost always occurs in the course of multiple sclerosis (MS). The lesions may be either clinically evident 33 or silent and only disclosed through electrophysiological ${ }^{12} \sim 14$ methods or autopsy studies 30. Conversely it has been demonstrated that a high proportion of patients who present isolated idiopathic optic neuritis (IION) goes on to develop demyelinating lesions outside the anterior optic pathways $3,4,6,8,9, n, i 3, i 5, i 6,18, i 9,2 i, 26,32,34,36,37,40,48,52,54$. The estimated risk of manifest MS developing in patients with HON is variable, the rates ranging from $11.5 \%^{20}$ to $85 \% 31$ in the literature. Several factors such as

* Associate Professor of Neurology, Department of Neurology, Federal University of Minas Gerais.

Dr. M. A. Lana Peixoto - Institute Hilton Rocha - Av Anel da Serra 1335 - 30210 Belo Horizonte $M G$ - Brasil. 
patient selection, diagnostic criteria, length of the follow-up, genetic predisposition, sex race and the geoghaphic location where the cohorts were studied may account for these differences. Series from different countries suggest that racial and geographic factors may also play an important role in the risk of conversion of HON to MS. Many studies in Europe 3,6,16,31,33,36,37,41,47,49,53, United States 46 and Australia 29,45 showed that the risk is over $50 \%$. On the other hand progression rates in Israel 18 and Japan 17 were estimated in $32 \%$ and $8.3 \%$ respectively. To trie best of our knowledge, in addition to a series from Chile 2 in which only one out of 23 patients with HON (4.3\%) developed MS in a mean follow-up period of 9.7 years, no other study in Latin America was conducted.

In order to evaluate the conversion rate of HON to MS in Brazil, a MS presumptively low prevalence country, a group of patients was observed during a mean follow-up period of 4.6 years. The results of this investigation are herein reported and discussed.

\section{PATIENTS AND METHODS}

Between 1980 and 1989136 patients with a presumable diagnosis of optic neuritis were examined by one of us (MALP) at the Neuro-Ophthalmology Department of the Institute Hilton Roeha, a national referral hospital for eye diseases in Belo Horizonte, Brazil. AH patients had full ophthalmic and neurologic examinations to rule out eye or CNS disorders. Patients with family history of visual failure, history of heavy tobacco or a alcohol comsuption, use of toxic substances, evidence of diabetes, hypertension, dietary deficiency, neurosyphilis, ischemic optic neuropathy, optic nerve vasculitis or compression, uveitis and retinal disorders were excluded. Patients with previous history of diplopia or any evidence of motor or sensation deficit, motor incoordination or sphincter disturbance were also discarted.

The diagnosis of optic neuritis according to the, criteria of Perkin and Rose 41 was then confirmed in 100 patients. Nine of them had history, or signs of neurologic disease in addition to optic neuritis and were therefore discarded. Three patients who developed optic neuritis in the course of or immediately after measles or mumps were also excluded. The remaining 88 patients were considered to present HON and are the subject of this study.

Patients were said to have bilateral optic neuritis when both eye were involved simultaneously or within four weeks of each other. Recurrent optic neuritis was defined as attacks of optic neuritis involving one or other eye at an interval greater than four weeks. When the recurrent episode affected the other eye the term sequential optic neuritis was employed 41 .

The period of follow-up was taken as the time from the original attack of optic neuritis to the time of the last reassessment, or in patients developing MS, to the time of development of other signs of CNS involvement. This period ranged from one month to 9 years (mean 4.6 years). Clinically definite or probable MS was diagnosed according to the criteria of Poser et al. 42 and the onset was dated to the first symptom that the patient could recall.

\section{RESULTS}

In 88 cases of HON there were 52 men and 36 women, the sex ratio being 1.4:1.0. The age at onset ranged from 3 to 59 years and the mean age was 24.3 years. Seventeen patients were 14 or less years old at the time of the optic neurits, 10 of them were 6 or less years old.

There were 19 patients $(21 \%)$ with bilateral optic neuritis and 19 others with sequential involvement of the fellow eye after an interval longer than four weeks. Recurrent episodes affecting the same eye was observed in seven patients (7.9\%). Most of the recurrences occurred in the first two years following the initial episode. The median age of patients with bilateral optic neuritis was 16 years whereas of patients with recurrences was 38 years.

Nine patients $(10.2 \%)$ developed clinical evidence of demyelination elsewhere in the CNS and were regarded as fulfilling the criteria for diagnosis of definite MS (Table 1). There were five out of 36 women $(13,9 \%)$ and four out of 57 men $(7.7 \%)$, with age ranging from 17 to 49 years at the time of diagnosis of MS; the median age being 25 years. Three of these patients had presented bilateral simultaneous optic neuritis (cases 5 , 6 and 8), whereas 


\begin{tabular}{|c|c|c|c|c|c|c|}
\hline Case & $\operatorname{Sex}$ & Age & Eye & Recurrences & $\begin{array}{c}\text { Interval } \\
\text { IION - MS }\end{array}$ & Developing signs \\
\hline 1 & $\mathbf{M}$ & 23 & OS & OD & 2 months & $\begin{array}{l}\text { Paraparesis; paresthesiae in } \\
\text { lower limbs }\end{array}$ \\
\hline 2 & $\mathbf{M}$ & 18 & os & os & 3 years & $\begin{array}{l}\text { Paresthesiae in lower limbs } \\
\text { weakness of rt. hand }\end{array}$ \\
\hline 3 & $\mathbf{M}$ & 40 & OD & OD & 1 year & Paresthesiae in lower limbs \\
\hline 4 & $\mathbf{F}$ & 26 & os & os & 5 years & $\begin{array}{c}\text { Paresthesiae in lower limbs; } \\
\text { sphincter dysfunction }\end{array}$ \\
\hline $\mathbf{5}$ & $\mathbf{M}$ & 27 & bilat. & & 1 year & Ataxia of limbs; ataxic gait \\
\hline 6 & $\mathbf{F}$ & 49 & bilat. & & 1 year & $\begin{array}{c}\text { Paraparesis; sensory level at } \\
\mathbf{T}_{\mathbb{A}} \text {; sphincter dysfunction }\end{array}$ \\
\hline 7 & $\mathbf{F}$ & 25 & OD & & 3 years & $\begin{array}{l}\text { Paraparesis; ataxia of limbs, } \\
\text { ataxic gait; sensory loss }\end{array}$ \\
\hline 8 & $\mathbf{F}$ & 17 & bilat. & & 1 month & $\begin{array}{l}\text { Diplopia; internuclear } \\
\text { ophthaimoplegia }\end{array}$ \\
\hline 9 & $\mathbf{F}$ & 20 & OD & os & 5 years & $\begin{array}{l}\text { Paralysis of rt. hand and face; } \\
\text { ataxia of limbs; ataxic gait }\end{array}$ \\
\hline
\end{tabular}

Table 1 - Optic neuritis patients developing multiple sclerosis.

sequential involvement of the fellow eye after an interval longer than four weeks occurred in two patients (cases 1 and 9 ), and recurrence in the same eye in other three patients (cases 2, 3 and 4). In just one patient (case 7), optic neuritis occurred in a single eye and Showed no recurrence until the time of the diagnosis of MS. In case 4 there were three episodes of recurrence in the same eye before clinical signs of MS developed.

The interval between IION and the emergence of other MS signs varied from one month to five years, with a mean of 26 months and a median of one year. In six out of nine patients $(67 \%)$ who progressed to MS there was predominant involvement of the spinal cord. Incoordination of the limbs and ataxic gait were the most marked clinical signs in two patients, whereas diplopia and internuclear opthalmoplegia occurred in one case.

\section{COMMENTS}

Multiple sclerosis in Brazil is presumably very rare although epidemiological studies have not been published to date. The risk of developing MS following HON is even less known in this country. A similar situation occurs throughtout Latin America and to the best of our knowledge, the only study on the progression of HON to MS in this continent comes from Chile 2 where just one among 23 patients with HON manifested MS in a mean follow-up period of 9.7 years. The present investigation shows that nine of 88 patients (10.2\%) who were first seen with HON eventually developed MS. This figure is much higher than the Chilean study but our sample is larger and derived from a private hospital usually attended by middle class or well-to-do people who are generally more attentive and have easier access to health care. Yet this rate may even be underestimated if one considers some relevant methodological points. First of all, although some of our patients had a follow-up time as long as 10 years, for many others this period was shorter than one year. It has been well recognized that the longer the follow-up the greater the chance of conversion 13.16,33,34,36. Secondly, it is possible that some patients who developed MS were lost for follow-up and have not notified us about the disease. It is also to be noted that as many as 17 patients $(27.3 \%)$ were 14 or less years old. Some authors 39 have found a very small risk or development of $M S$ in this age group although others 44 have demonstrated, on clinical grounds and by magnetic resonance imaging (MRI), conversion rates as high as those of adults. If children were excluded from our series the progression rate would increase to 9 of 61 patients (14.7\%). 
As gender is concerned as risk factor for the development of MS our analysis shows that $13.5 \%$ of the women and $7.7 \%$ of the men progressed to MS. The greater risk in the women is in agreement with other studies 3,8,15,46. Some authors reported a risk 3.4 times greater in women than in men 46.

Bilaterality and recurrences have also been considered as risk factors 8,9,17,52 In the present investigation MS developed in five of 38 patients $(13.2 \%)$ who had simultaneous or sequential optic neuritis or in four of $52(8 \%)$ who had unilateral involvement. Three of these last patients had had recurrent episodes of HON coming before MS. This positive influence of recurrence has not been confirmed by other autors $16,19,46$.

The longest interval between HON and the onset of clinical signs of lesions elsewhere was five years in our study. Most patients who converted to MS had clinical signs one year after onset of the HON. Although the majority of investigations demonstrate that the risk of progression to MS is greater in the first years following HON 6,10,16,19,29,40,45,48,54, reassessment after extended follow-up and life table analysis have revealed an actual increment of the risk as time goes on 13,46. Rizzo and Lessell 46 observed no decline in the risk of developing MS after the first several years

\begin{tabular}{|c|c|c|c|c|c|c|}
\hline Author & Diate & Country & $\begin{array}{l}\text { Num- } \\
\text { ber of } \\
\text { cases }\end{array}$ & $\begin{array}{c}\text { Follow-up } \\
\text { mean } \\
\text { (range) }\end{array}$ & $\begin{array}{c}\% \\
\text { Definite } \\
\text { MS }\end{array}$ & $\begin{array}{c}\% \text { Prob/ } \\
\text { Possible } \\
\text { MS }\end{array}$ \\
\hline Rose 47 & 1970 & England & 91 & $\begin{array}{c}? \\
(0.5-7)\end{array}$ & $\mathbf{5 5}$ & - \\
\hline Sandberg-Wolheim 48 & 1975 & Sweden & 60 & $\begin{array}{c}13.3 \\
(0.5-6)\end{array}$ & 36 & - \\
\hline Compston et al.9 & 1978 & England & 146 & $\begin{array}{c}? \\
(0.8-3.5)\end{array}$ & 25 & 15 \\
\hline Cohen et al.o & 1979 & USA & 60 & $\begin{array}{c}7.1 \\
(5-12)\end{array}$ & 28 & 7 \\
\hline Nikoskelainen et al.36 & 1981 & Finland & 48 & $\begin{array}{c}? \\
(7-10)\end{array}$ & - & $56 / 19$ \\
\hline DeLeersnyder et al.10 & 1981 & France & 14 & $\begin{array}{c}1.07 \\
(0.25-3)\end{array}$ & 21 & - \\
\hline Isayrama et al.17 & 1982 & Japan & 84 & $\begin{array}{c}5.2 \\
(1-11.8)\end{array}$ & 8.3 & - \\
\hline Stendal-Brodin and Link 52 & 1983 & Sweden & 30 & $\begin{array}{c}11 \\
(6-20)\end{array}$ & 33 & 一 \\
\hline Kinnunen 19 & 1983 & Finland & 214 & $\begin{array}{c}5.1 \\
?\end{array}$ & 19 & 一 \\
\hline Landy 29 & 1983 & Australia & 110 & $?$ & 56 & - \\
\hline Mapelli et al.32 & 1985 & Italy & 54 & $\begin{array}{c}9.2 \\
(5-16)\end{array}$ & 25 & - \\
\hline Hely et al.15 & 1986 & Australia & 82 & $\begin{array}{c}4.8 \\
(0.5-22)\end{array}$ & 32 & - \\
\hline Rizzo et al.46 & 1988 & USA & 60 & $\begin{array}{c}14.9 \\
(5-20.5)\end{array}$ & 58 & 一 \\
\hline Sanders et al.49 & 1989 & Netherlan & ad 48 & $\begin{array}{c}? \\
(0.5-3.5)\end{array}$ & 60 & 一 \\
\hline Alvarez et al.2 & 1989 & Chile & 23 & 9.7 & 4.3 & 一 \\
\hline Present series & & Brazil & 88 & $\begin{array}{c}4.6 \\
(0.1-9)\end{array}$ & 10.2 & 一 \\
\hline
\end{tabular}

Table 2 - Prospective studies on the correlation between IION and MS in different countries. 
of follow-up. Conversely, they report, through life table analysis, that $74 \%$ of the women and $34 \%$ of the men in their cohort would have developed MS within 10 years after their initial attack of HON, and that after 20 years of follow-up $91.3 \%$ of the women and $44.8 \%$ of the men would be expected to develop $M S$. It is conceivable that as follow-up of subjects in our cohort extends or if life table analysis is used the rate of conversion may increase. At the present time however, among all published prospective studies, our figure is only smaller than those in Chile and Japan (Table 2). It is still uncertain if geographical factors may influence the prognosis of HON. Distinct study designs and particular methodological aspects are always to be considered to account for the different results 26 . However dissemination rates in different MS prevalence zones seem relate directly to the prevalence of MS in those areas. In general, series in Northern-European countries 3,36,47,49 show the greatest progression rates whereas they have been variably reported in the United States 4,8,33,40,46,54 nd Australia 15,29,45 $i_{n}$ Israel is, Japan 17 and Chile 2 dissemination to MS is unfrequent.

In Japan a prospective study of 84 patients with HON showed a conversion rate of $8.3 \%$ in a mean follow-up period of 5.2 years 1?. This rate is very close to ours and it turns to be another point of similarity of $M S$ in eastern countries and Brazil. It is known that $M S$ in Japan 22,25.50,5i, Korea 27, India 7,35 and China 5 has a low prevalence rate, a higher frequency of visual symptoms at the onset and a predominant involvement of the optic nerves and spinal cord. In Brazil the disease presents similar clinical features 28. An example of this tendency is the occurrence of spinal cord signs in six of our nine patients $(67 \%)$ who developed MS. In the Japanese group spinal cord involvement was present in $85.7 \%$ of the MS patients $1^{7}$ Asian and Latin American countries may share common factors influencing the expression of the disease and the progression of HON to MS.

\section{REFERENCES}

1. Alter M, Good J, Okihiro M. Optic neuritis in Orientals and Caucasians. Neurology 1973, $23: 631$.

2. Alvarez G, Cárdenas M. Multiple sclerosis following optic neuritis in Chile. J Neurol Neurosurg Psichiat 1989, 52:115.

3. Anmarkrud N, Slettnes ON. Uncomplicated retrobulbar neuritis and the development of multiple sclerosis. Acta Ophthalmol 1989, $67: 306$

4. Appen RE, Allen JC. Optic neuritis under 60 years of age. Ann Ophthalmol 1974, 6:143.

5. Baoxun Z, Xiuqin L, Yupu G, Yinchang Y, Huifen H. Multiple sclerosis: a clinical study of 70 cases. Chin Med J 1980, 93 : 260.

6. Bradley WR, Whitty CWM. Acute optic neuritis: its clinical features and their relation to prognosis for recovery of vision. J Neurol Neurosurg Psychiat 1968, $31: 18$.

7. Chopra JS, Radhakrishnan K, Sawhney BB, Pal SR, Banerjee AL. Multiple sclerosis in North West India. Acta Neurol Scand 1980, $62: 312$

8. Cohen MM, Lessel S, Wolf PA. A prospective study of the risk of developing multiple sclerosis in uncomplicated optic neuritis. Neurology 1979, $29: 208$

9. Compston DAS, Batchelar JR, Earl CJ, McDonald WI. Factors influencing the risk of multiple sclerosis developing in patients with optic neuritis. Brain 1978, $101: 495$.

10. DeLeersnyder H, Bursztyn J, Ponsot G, Dulac O, Arthuis M. Nevrites optiques de l'enfant: aspects cliniques et évolutifs à propos de 14 observations. Arch Fr Pediatr 1981, $38: 563$.

11. Feasby TE, Ebers GE. Risk of multiple sclerosis in isolated optic neuritis. Can J Neurol Sci 1982, $9: 269$.

12. Feinsod M, Hoyt WF. Subclinical optic neuropathy in multiple sclerosis: how early VER components reflect axon loss land conduction defects in optic pathways. J Neurol Neurosurg Psichiat 1975, $38: 1109$.

13. Francis DA, Composton DAS, Batchelor JR, McDonald WI. A ressessment of the risk of multiple sclerosis developing in patients with optic neuritis after extend follow-up. J Neurol Neurosurg Psichiat 1987, 50 : 758.

14. Halliday AM, McDonald WI, Mushin J. Visual evoked response in diagnosis of multiple sclerosis. Br J Med 1973, 4 : 661.

15. Hely MA, McManis PG, Doran TJ, Walsh JC, Mcleod JG. Acute optic neuritis: a prospective study of risk factors for multiple sclerosis. J Neurol Neurosurg Psichiat 1986, $49: 1125$. 
16. Hutchinson WM. Acute optic neuritis and the prognosis for multiple sclerosis. J Neurol Neurosurg Psychiat 1976, 39 : 283.

17. Isayama $\mathrm{Y}$, Takahashi $\mathrm{T}$, Shimoyoma $\mathrm{T}$, Yamadori A. Acute optic neuritis and multiple sclerosis. Neurology 1982, $32: 73$.

18. Kahana E, Alter M, Feldman S. Optic neuritis in relation to multiple sclerosis. J Neurol $1976,213: 87$.

19. Kinnunen E. The incidence of optic neuritis and its prognosis for multiple sclerosis. Acta Neuroi Scand 1986, 68 : 371.

20. Kurland LT, Auth TL, Beebe GW, Kurtzke JF, Lessell S, Nagler B, Nefzger MD. Studies on the natural history of multiple sclerosis: II. Progression from optic neuropathy to multiple sclerosis. Trans Am Neurol Assoc 1963, 88 : 233.

21. Kurland LT, Beebe GW, Kurtzke JF, Nagler B, Auth TL, Lessell S, Nefzger MD. Studies on the natural history of multiple sclerosis: II. The progression of optic neuritis to multiple sclerosis. Acta Neurol Scand 1966, 42(suppl 19):157.

22. Kuroiwa Y, Hung TP, Landsborough D, Park CS, Singlall BS, Soemargo S, Vejajyiva A Shibasaki H. Multiple sclerosis in Asia. Neurology 1977, $27: 188$.

23. Kuroiwa Y, Igata A, Itahara A, Koshijima S, Tsubaki T, Toyokura Y, Shibasaki H Nationwide survey of multiple sclerosis in Japan: clinical analysis of 1084 cases. Neurology $1975,25: 845$.

24. Kuroiwa Y, Shibasaki H. Multiple sclerosis: general view. Adv Neurol Sci (Tokyo) 1975, $19: 5$.

25. Kuroiwa Y, Shibasaki H, Inone N. Epidemiologic study of multiple sclerosis group in Japan. Adv Neurol Sci (Tokyo) 1970, 14 : 607.

26. Kurtzke JF. Optic neuritis or multiple sclerosis. Arch Neurol 1985, 42 : 704.

27. Kurtzke JF, Park CS, Oh SJ. Multiple sclerosis in Korea: clinical features and prevalence. J Neurol Sci 1968, $6: 463$.

28. Lana-Peixoto MA. Is multiple sclerosis in Brazil and Asia alike? In preparation.

29. Landy PJ. A prospective study of the risk of developing multiple sclerosis in optic neuritis in a tropical and subtropical area. J Neurol Neurosurg Psychiat 1983, 46:659.

30. Lumsden CE. The neuropathology of multiple sclerosis. In Vinken PJ, Bruyn GW (eds) : Handbook of Clinical Neurology. Amsterdam: North Holland, 1970, Vol 9, p 217-309.

31. Lyn BH. Retrobulbar neuritis: a survey of the present condition of cases occuring over the last fifty-six years. Trans Ophthalmol Soc UK 1959, 79 : 701.

32. Mapelli G, De Palma P, Fini M, Piavoni M, Franco P, Pirazzoli G. Retrobulbar optic neuritis as an initial sympton of multiple sclerosis: results of a prospective study. Riv Neurol 1985, 55 : 53.

33. McAlpine D, Lumsden CE, Acheson ED. Multiple sclerosis. A Reappraisal. Edinburgh: Livingstone, 1965.

34. McDonald WI - Doyne Lecture: The significance of optic neuritis. Trans Ophthalmol Soc UK 1983, $103: 230$.

35. Nair KR, Sahasranam KV. Multiple sclerosis in Malabar. J Ass Physicians India 1978, $26: 893$.

36. Nikoskelainen E, Frey H, Salmi A. Prognosis of optic neuritis with special reference to cerebrospinal fluid immunoglobulins and measles virus antibodies. Ann Neurol 1980, 9:545.

37. Nikoskelainen E, Riekkinen P. Optic neuritis: a sign of multiple sclerosis or other diseases of the nervous system. Acta Neurol Scand 1974, 50 : 590.

38. Nordmann JP, Saraux H, Roullet E. Contrast sensitivity: a study in 35 patients with and without optic neuritis. Ophthalmologica 1987, $195: 199$.

39. Parkin JP, Hierons R, McDonald WI. Bilateral optic neuritis: a logn-term follow-up. Brain 1984, 107 : 951.

40. Percy AK, Nobrega FT, Kurland LT. Optic neuritis and multiple sclerosis. Arch Ophthalmol 1972, 87:135.

41. Perkin GD, Rose FC. Optic Neuritis and its Differential Diagnosis. Oxford: Oxford Univ Press, 1979.

42. Poser CM, Patty DW, Scheinberg L, McDonald WI, Davis FA, Ebers GC, Johnson KP, Sibley WA, Silberberg DH, Tourtellotte WW. New diagnostic criteria for multiple sclerosis: guidelines for research protocols. Ann Neurol 1983, 13 : 227.

43. Regan D, Silver R, Murray TJ. Visual acuity and contrast sensitivity in multiple sclerosis: hidden visual loss, an auxiliary diagnostic test. Brain 1977, 100:563.

44. Rikonen R, Ketonen L, Sipponen J. Magnetic resonance imaging, evoked responses and cerebrospinal fluid findings in a follow-up study of children with optic neuritis. Acta Neurol Scand 1988, $77: 44$. 
45. Rischbieth RHC. Retrobulbar neuritis in the state of South Australia. Proc Aust Assoc Neurol 1968, $5: 573$.

46. Rizzo JF, Lessel S. Risk of developing multiple sclerosis after uncomplicated optic neuritis. Neurology 1988, $38: 185$.

47. Rose FC. The aetiology of optic neuritis. Clin Sci 1970, 39 : 17P

48. Sandberg-Wolheim M. Optic neuritis: studies on the cerebrospinal fluid in relation to clinical course in 61 patients. Acta Neurol Scand 1975, 52 : 167.

49. Sanders EACM, Van Lith GHM. Optic neuritis confirmed by visual evoked response and the risk for multiple sclerosis: a prospective survey. J Neurol Neurosurg Psichiat $1989,52: 799$.

50. Shibasaki H. Kuroda Y, Iwashita H. Clinical studies of multiple sclerosis in Japan: multiple sclerosis starting with retrobulbar neuritis. J Neurol 1974, 208 : 17

51. Shibasaki H, Kuroda Y, Kuroiwa Y. Clinical studies of multiple sclerosis in Japan: classical multiple sclerosis and Devic's disease. J Neurol Sci 1974, 23:215.

52. Stendahl-Brodin L, Link H. Optic neuritis: oligoclonal bands increase the risk of multiple sclerosis. Acta Neurol Scand 1983, 67:301.

53. Stendahl-Brodin L, Link H, Möller E, Noorby E. Optic neuritis and the distribution of genetic markers of the HLA system. Acta Neurol Scand 1978, 57 : 418.

54. Taub RG, Rucker CW. The relationship of retrobulbar neuritis to multiple sclerosis. Am J Ophthalmol 1954, 32 : 488. 